\title{
EYSIER Charter Mark with ABCDE and Assessment for Personal and Social Learning; a Bottom-up Approach to Building Faculty of Judgement with an Open Access Knowledge Base of Science with and for Society (Swafs)
}

\author{
Alison Taysum \\ External Examiner University of Ulster \\ Marc Beutner \\ University Paderborn, Germany \\ Arto Kallioniemi \\ University of Helsinki, Finland
}

\section{Abstract}

Civic society must mobilise education and training to move from Covid 19 disruption to recovery to meet the goals established by the President of the European Commission "A Union that strives for more " and promoted through the European Education Area. Using Five stages of 'A Blueprint for Character Development for Evolution' (ABCDE), citizens map their journey to making good decisions in a new social contract to amplify recovery. A is European Qualifications Framework (EQF) Level 1 to ask good questions to solve problems; What is social distancing? How can I optimise success in virtual-classrooms? How can I safely create a new job for myself? B is EQF Competence Level 2 and focusses to explore the best that has been thought and said from explicit Scientific/social knowledge and synthesise it with implicit personal knowledge/beliefs, to gain shared understandings of definitions of terms. $\mathrm{C}$ is EQF Competence Level 3 to develop robust methods for data-collection/handling to find solutions to personal and social, cultural, health, economic and political problems. D is EQF Competence Level 4 to develop theories of change from data as solutions to social and personal problems for recovery. E is EQF Competence Level 5 to develop moral and ethical principles in a new social contract. ABCDE is implemented with 'Assessment for Personal and Social Learning', A Massive Online Open-Access Course, and toolkit to gain the Empowering Young Societal Innovators for Equity and Renewal (EYSIER) Charter Mark to align commercial, humanitarian evolutionary and sustainable goals to propel recovery.

Keywords: EYSIER, charter, ABCDE, assessment, personal, social, learning, bottomup, approach, building, open access knowledge, base of science, society, Swafs 


\section{Introduction}

\section{The Professional Challenge, its illucidation, and Objectives and Research Questions}

Civic society must mobilise education to move from the unprecedented disruption caused by Covid 19 to recovery. A barrier exists to this recovery because civic society is locked out of fully and freely participating with the data collection and handling in the social quadruple helix that empowers community solutions to amplify recovery. The persistent inequalities in society are exacerbating recovery because of Society's deep mistrust of the role of scientific evidence, experts, and psychologies, philosophies and ethics of trust. In a quadruple helix of University, industry, government, and citizens and the social media there is a lack of mainstreaming innovative knowledge between the four sub-groups to underpin effective recovery from the unprecedented disruption caused by Covid 19. New partnerships are required to propel entrepreneurial economies with and for social cohesion that celebrates cultural diversity. These new partnerships align commercial goals that socialise risks, investments and rewards in a new ethical, logical and evidence informed social contract that does no harm to the self or the other, that all citizens explicitly understand in terms of duties and rights, such that they could have written the contract themselves (Kant, 1785) in a font size they can read.

The social contract is between subgroups of the quadruple helix; citizens and social media, the economy (industry) the government and their governance of institutional policies (including Universities) and systems of knowledge generation, exchange and transmission in Higher Education Institutions (HEI). HEIs supervise education systems to propel successful consumption of innovative knowledge on bridges between subgroups to align commercial, human evolutionary and sustainable interests/goals. Taysum (2019) identifies the independent legislator in the quadruple helix monitors and evaluates the alignment of commercial interests, humanitarian evolutionary interests, and the ethical and moral sustainable interests found in the complexities of the quadruple helix policies as text and policies as discourse (Taysum, 2019, Ball, 2006). Open Access bottom up data bases of Science with and for Society (SwafS 31, Horizon 2020) with education systems that provide EQF competences to assure acitizens know how to participate with these data-bases effectively can eradicate fake news. This is because a person meeting Competences of the EQF Levels 1 - 5 mapping to $A B C D E$ has the cultural capital needed to make good decisions with good faculty of judgement using 'A; their own questions', 'B Science with and for Society', 'C methods', 'D developing theories of change and testing them for proof of concept', 'E arriving at principles that they can apply to other social problems'. Thus operationalising $\mathrm{ABCDE}$ allows citizens to penetrate fake news revealing the inequalities to the elites.

The best Universities in the world, including Oxford University, teach Philosophy, Politics, and Economics (PPE) to the future leaders of government. Knowledge is 
power (Bourdieu, 1993) thus access to PPE knowledge bases for the elite assures the elite's human evolution, but not the human evolution of the masses which is a barrier to equity and arguably a a factor that if addressed could accelerate achieving SDG 1; Eradicating Poverty (United Nations, 2016). The gap between the elite and others in the mobilisation of knowledge of and with society needs addressing urgently for issues of equity and access to middle class benefits as a threshold of minimum wealth for all. For example, one definition of philosophy is to think about the problems of the world. Education systems currently operate to satisfy testing industries, rather than equipping students with the EQF Level 1 - 5 competences required to become selfgoverning autonomous mature citizens who i) explicitly understand the social contract, ii) could have written the social contract and iii) can name the prime moral principles that assure the social contract has logical, evidence informed and a sustainable ethical framework for human rights and duties that do no harm to the self or the other. Education policy with a goal of students attaining a high rank in the testing industries league tables, has narrowed the curriculum and left students memorising facts to pass tests (Taysum, 2019; Taysum and Arar, 2018; Taysum and Collins-Ayanlaja, 2020). The noble intention of PISA was to provide benchmarking data for nation's education systems. The reality of the PISA model took on an ontology (what is) of its own and became the model of reality (Bhaskar, 2008). The objectives of education systems became high performance in tests to deliver a high rank in PISA. Taysum (2019) identifies using both quantitative tabular data and qualitative narrative data there is no correlation between PISA ranking and a nation state's Unit Labour Costs, its Gross Domestic Product (GDP), GDP per capita, levels of crime, the healthy aging and happiness of citizens and levels of trust in governance systems.

Three objectives address the professional challenge that was the focus of the development of a bid to address the Horizon 2020 Call SwafS 31.

Build effective co-operation between science and society by training leaders of the four spheres of the quadruple helix to use a toolkit mapped to the MoRRi that optimises delivery of their organisation's strategic plan and delivery of the SDG targets through interactions with open access Bottom up SwafS knowledge bases that propels recovery from Covid 19;

Foster the recruitment of new talent for science using a toolkit that delivers interactions with a bottom up SwafS knowledge base that builds scientific groups for all in STEM, the Social Sciences and Arts and Humanities;

Pair scientific excellence with social awareness and responsibility raising awareness of what to do to interact with the 8 lines of action, how to do this using the methodology of this Research in Action, and why these intentions and acts are of personal and social benefit and amplify the main SwafS' objectives that aid recovery from Covid 19.

The consortium address these objectives with the following Research Questions: 
How and in what ways can the consortium build effective co-operation between science and society to propel recovery from Covid 19 with leaders of the four spheres of the quadruple helix using a toolkit mapped to the MoRRi that optimises delivery of their organisation's strategic plan through interactions with open access Bottom up SwafS knowledge bases?

How and in what ways can the consortium foster the recruitment of new talent for science using a toolkit that delivers interactions with a bottom up SwafS knowledge base that builds scientific groups for all in STEM, the Social Sciences and Arts and Humanities for recovery from Covid 19?

How and in what ways can the consortium pair scientific excellence with social awareness and responsibility raising awareness of what to do to interact with the 8 lines of action ${ }^{1}$ to propel recovery, how to do this using the methodology of this project and why these intentions and acts are of personal and social benefit and amplify the main SwafS' objectives to propel recovery from Covid 19?

\section{Building effective co-operation between science and society with competences for selfgoverning autonomous citizens}

Interacting with bottom up Open Access SwafS knowledge bases in terms of mobilising citizens' consumption of research to address the targets of the Sustainable Development Goals is important. This gives young people the chance to apply their new knowledge to the disciplines in their lifelong learning. This may enable young people in intergenerational and collaborative problem solving networks across the quadruple helix to ask good questions about their professional challenge(s)/problem(s) which is Stage A of ABCDE (Diagram 1). Stage B is engagement with knowledge bases that allow the synthesis between personal implicit knowledge and external scientific knowledge using Assessment for Personal and Social Learning (APSL) (Diagram 2). By using APSL at Stage B citizens have a toolkit to engage with Science with and for Society in new partnerships between science and society.

\section{Diagram 1 A Blueprint for Character Development for Evolution (ABCDE) (Taysum, 2019, p.76)}

Education Policy as a Roadmap for Achieving the SDGs

\begin{tabular}{|l|l|l|l|l|l|}
\hline $\begin{array}{l}\text { Stage of Character } \\
\text { Development }\end{array}$ & Why? & $\begin{array}{l}\text { Transition from } \\
\text { Immaturity to }\end{array}$ & $\begin{array}{l}\text { Impact } \\
\text { on }\end{array}$ & $\begin{array}{l}\text { Participati } \\
\text { on in }\end{array}$ & Likely \% of \\
Paturity & Mental & Constructi & to Turn Out \\
Health & ng Social & to \\
Contract & Vote
\end{tabular}

\footnotetext{
${ }^{1}$ The eight lines of action are science careers, gender equality, public engagement, science education, open access/open data, governance and ethics, the precautionary principle, science communication.
} 


\begin{tabular}{|c|c|c|c|c|c|}
\hline $\begin{array}{l}\text { Al, Obeys rules driven by } \\
\text { fear }\end{array}$ & $\begin{array}{l}\text { Senses fear of } \\
\text { punishment }\end{array}$ & $\begin{array}{l}\text { Continues to } \\
\text { fear institutions } \\
\text { in behaviourist } \\
\text { fight of flight } \\
\text { mode }\end{array}$ & $\begin{array}{l}\text { Poor } \\
\text { mental } \\
\text { health }\end{array}$ & None & Low \\
\hline $\begin{array}{l}\text { A2. Obeys rules driven by } \\
\text { getting even }\end{array}$ & $\begin{array}{l}\text { Senses fear and } \\
\text { seeks revenge if they } \\
\text { arc wronged }\end{array}$ & $\begin{array}{l}\text { Continues to } \\
\text { fear institutions } \\
\text { and seek } \\
\text { revenge for } \\
\text { wrongs done - } \\
\text { may be high } \\
\text { vigilance }\end{array}$ & $\begin{array}{l}\text { Poor } \\
\text { mental } \\
\text { health }\end{array}$ & None & Low \\
\hline $\begin{array}{l}\text { B. Obeys rules underpinned } \\
\text { by beliefs }\end{array}$ & $\begin{array}{l}\text { Believes in doing } \\
\text { things right but does } \\
\text { not know why in } \\
\text { practice }\end{array}$ & $\begin{array}{l}\text { Confused } \\
\text { which is linked } \\
\text { to ambiguity } \\
\text { which can lead } \\
\text { to perpetuating } \\
\text { VUCA } \\
\end{array}$ & $\begin{array}{l}\text { Poor } \\
\text { mental } \\
\text { health }\end{array}$ & Low & $\begin{array}{l}\text { Low - } \\
\text { medium }\end{array}$ \\
\hline $\begin{array}{l}\text { C. Obeys rules and } \\
\text { chooses to do duty within } \\
\text { the law with methods and } \\
\text { theories to help predict } \\
\text { consequence of acts with } \\
\text { missing information }\end{array}$ & $\begin{array}{l}\text { Developed methods } \\
\text { to find out how others } \\
\text { have done the right } \\
\text { thing or not with good } \\
\text { application of } \\
\text { concepts in practice } \\
\text { for a good social } \\
\text { contract and } \\
\text { embedded economy. }\end{array}$ & $\begin{array}{l}\text { Potential for } \\
\text { enlightenment } \\
\text { and human } \\
\text { evolution }\end{array}$ & $\begin{array}{l}\text { Potential } \\
\text { for good } \\
\text { mental } \\
\text { health }\end{array}$ & High & High \\
\hline $\begin{array}{l}\text { D. Obeys rules and } \\
\text { chooses to do duty within } \\
\text { the law and develops } \\
\text { hypotheses to test for proof } \\
\text { of concept to inform future } \\
\text { good decision making. }\end{array}$ & $\begin{array}{l}\text { Developed } \\
\text { hypotheses to do the } \\
\text { right thing with good } \\
\text { application of } \\
\text { concepts for a good } \\
\text { social contract and } \\
\text { embedded economy }\end{array}$ & $\begin{array}{l}\text { Potential for } \\
\text { enlightenment } \\
\text { and human } \\
\text { evolution }\end{array}$ & $\begin{array}{l}\text { Potential } \\
\text { for good } \\
\text { mental } \\
\text { health }\end{array}$ & High & High \\
\hline $\begin{array}{l}\text { E. Obeys rules and } \\
\text { connects duties with rights } \\
\text { systematic moral inquiry } \\
\text { into the ethical rules and } \\
\text { leadership of institutions }\end{array}$ & $\begin{array}{l}\text { Has arrived at and is } \\
\text { guided by universal } \\
\text { ethical principles } \\
\text { applied to the social } \\
\text { life that have stood } \\
\text { the test of } \\
\text { Assessment for } \\
\text { Personal and Social } \\
\text { moral inquiry }\end{array}$ & $\begin{array}{l}\text { Enlightened } \\
\text { human in } \\
\text { becoming } \\
\text { contributing to } \\
\text { human } \\
\text { evolution }\end{array}$ & Good & High & High \\
\hline
\end{tabular}

Fig. 4.1. Taysum (BERA, 2018c) Five Stages of Character Development to Build Trust in the Social Contract Applying ABCDE. 
Diagram 2 Assessment for Personal and Social Learning (Taysum, 2020, p. 58)

Education Policy as a Roadmap for Achieving the SDGs

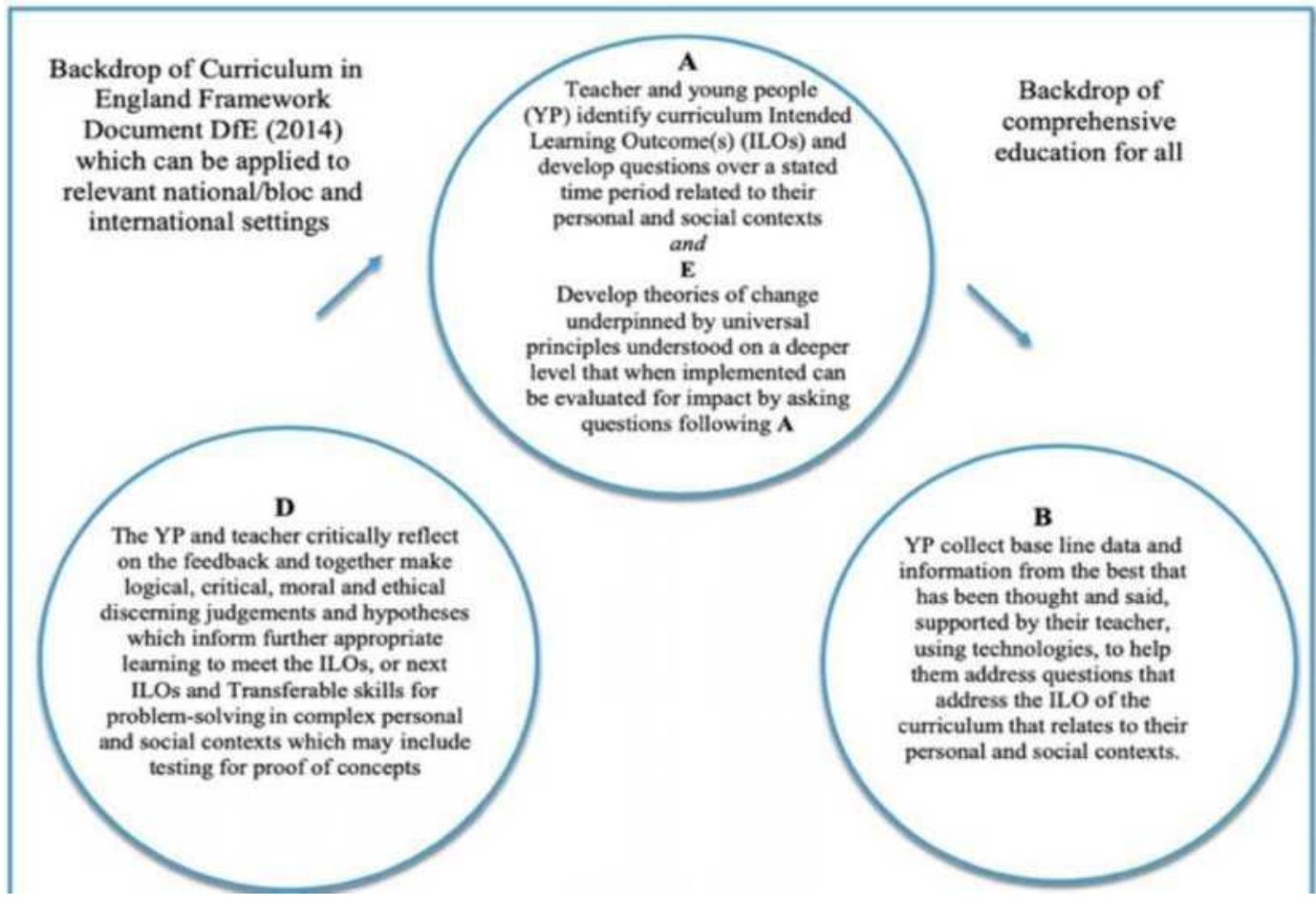

Backdrop to develop learning how to learn and self-efficacy to promote good mental health and aim to reduce $£ 105$ billion annual cost on treating mental health problems.

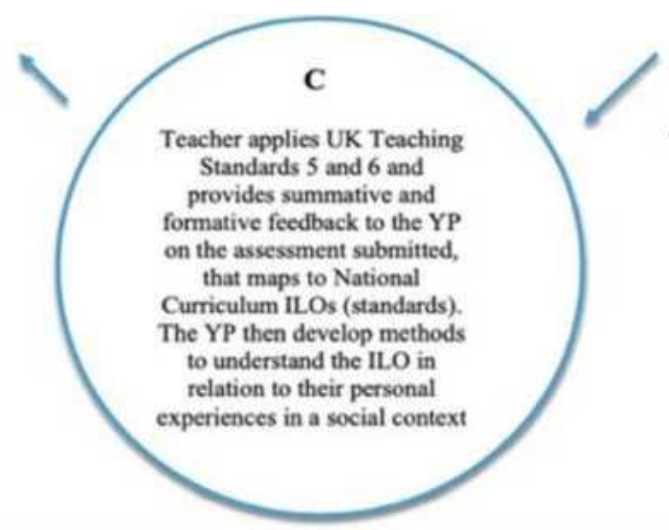

Backdrop of transforming Assessment to label failures to Assessment for Learning 
articulate their own questions. Mayssa (2020) draws on Dewey (1916) that a well articulated question holds half of the answer. Therefore, citizens can develop the competence of becoming their own midwife as wise leaders and gatekeepers of SwafS to examine their lives on a personal and social level using APSL (Diagram 2). Such autonomous citizens can address their professional challenges and move from a position of fear with a clear understanding that citizens are not afraid of the shadows, they are afraid of what is in the shadows that might harm them. Thus citizens can use ABCDE with APSL as a toolkit to fully participate with SwafS knowledge bases. The toolkit gives them the thinking tools to understand the self and identify the root causes of their confusion and fear of the things and the people that could do them harm in the quadruple helix. This aligns with Kant's (1785) Groundwork of the Metaphysics of Morals that the supreme principle of morality is that an autonomous rational being expresses a rational goodwill. This goodwill is expressed and the expression is fully explicit and fully known to that rational being, and they can make the moral laws and abide by the moral laws that all others would be happy to also arrive at if they had to make them as rational beings.

\section{Integration of MOOC types within the quadruple helix approach of the SwafS knowledge base}

To address all the four spheres of the quadruple helix - helix 1: academia/universities, helix 2: industry/business, helix 3 state/government and helix 4: Media based and culture-based public and civic society - (cf. Carayannis / Campbell 2011, 327), the consortium decided to have a focus on the design and adjustment of MOOCs. "A MOOC is a Massive Open Online Course, which is a series of seminars or workshops provided via internet for a group of people that is in most cases huge and that is easy and free to access and which is provided in most cases without fees or payments." (Beutner $2020,2)$ MOOCs have fundamental potential for a change in education in the digital age over the past few years (cf. Buchmann 2013, 5). This potential can be used to improve and enhance the communication of science as well as the collaboration and cooperation within the quadruple helix. Also with regard to the quintuple helix, where the natural environment of society is addressed as well, meaningfulness and efficiency of using MOOCs can be fully realised.

The aspects that MOOCs can be massive, which means that they are able to address many people all over the world with the course, and that a group of participants can be very large and diverse is a crucial aspect, when it comes to the use of MOOCs within the SwafS knowledge base. Here, the core idea is to address different target groups and offer a perspective to provide learning and teaching to many people.

The characteristic of openness of MOOCs provides conclusions about the modality of use (see as well Buchmann 2013,14). MOOCs provide knowledge in an open way which means open for everybody and this includes all four groups of the quadruple helix. Open also refers to the opening of education to underrepresented classes, which is achieved through the free availability of learning material (cf. Karall 2015, 22). 
xMOOCs, or extension MOOCs are based on traditional university courses which is a strength, but do not provide the student-teacher relationships Universities offer. They represent the most well-known form of MOOCs in the media. They contain clearly defined learning objectives and follow a strict schedule which can deliver and test existing knowledge. Frequently, certificates or degrees can also be obtained through these MOOCs.

More openness with regard to openness of thinking can be reached with cMOOCs, the connectivism MOOCs allows knowledge sharing and knowledge creation and therefore provide opportunities to innovate which, propelled with the digital age for which the required competences for successful engagement with the labour market are not yet known, can offer a very attractive learning as a self-organized process in networks. Unlike the xMOOCs, the learning objectives are not so clearly defined because they allow for innovation. Nevertheless, they are based on the interaction of the participants. The participants of a cMOOC can contribute to the course environment through blog posts, videos or forum articles and actively shape them. This makes cM0OCs less predictable, since the participants autonomously control how they organize the course. And this also means that this form of MOOCs also require a certain degree of digital competence.

Using MOOCs as an online approach offers the opportunity to combine real-time interaction with eLearning elements and interactive knowledge provision using the scope of the internet, the hyperlink possibilities and combinations with face-to-face learning like in so-called bMOOCs, the blended MOOCs. Basically, this concept is based on the combination of online course formats and traditional face-to-face events.

In 2020 Beutner could find that MOOCs are usually available for a longer time, are easy to structure, offer the opportunity to integrate tasks and tests, provide innovative learning and increase the motivation of learners and knowledge exchangers (cf. Beutner 2020, 5). Moreover he could underpin authentic learning with MOOCs via the integration of real pictures and images, video documentation and integration in MOOCs and via emotional connections (cf. Beutner 2020, 5). The core aspect in transferring knowledge and competences via MOOCs is putting skills/competences into practice. These link to the ET2020 Four Strategic Objectives. This can be reached by integration of practical problems/professional challenges, initiating group work possibilities, offering networking opportunities and interactivity as well as via real examples within the MOOC. This can also be fostered with links to additional real life materials and additional pedagogical materials (cf. Beutner 2020,5). Thus the MOOCs afford opportunities for participatory grassroots up databases of Science with and for Society.

The specific focus of MOOCs should be on the processes and practices of learning and teaching and not so much on technical issues. According to Beutner 2020 the structure of the MOOC and its content, providing feedback opportunities, and adequate addressing of different target groups are much more important and often 
go hand in hand with content development and the use of Open Educational Resources (OER). Within a SwafS knowledge base approach there will also be the crucial element of evaluating the MOOC as tool, the learning and knowledge exchange processes provided by the MOOC, and the project aims and objectives. A basis for such an Evaluation are the approaches of Scriven (2007) with his distinction of summative, formative and ascriptive evaluation which is the evaluation of the evaluation process (see as well Beutner 2018, 120 ff, Dewey, 1909.)

Michael Scriven consequently stated: "Evaluation is the process of determining merit, worth, or significance; an evaluation is a product of that process. Professional evaluation is evaluation done in a systematic and objective way with a degree of expertise that requires extensive specific training or learning (Scriven 2007). In addition to the Scriven approach also elements of other qualitative and use-oriented evaluations are taken into account. These are approaches like the responsive evaluation of Stake (Stake 1975) and constructivist evaluation of Guba / Lincoln (Guba/Lincoln 1989), the levels of evaluation according to Kirkpatrick (Kirkpatrick 1959a, 1959b, 1959c, 1960a, 1960b) as well as the new Context -Input - Process Product (CIPP) model of Stuffelbeam (Stuffelbeam 2004). Designing the knowledge base and the evaluation process will include a focus on blind spots of research and innovation. People's needs and concerns have to be taken into account, as well as scientific uncertainty, means of measuring the integration of MoRRI in science and innovation, and the gender dimension in research content. MOOCs can foster understanding the co-evolution of science and society. Moreover they use of MOOCs within the knowledge base supports anticipatory policy making and a transition to open science. Here also the already mentioned open educational resources may help to work on the changes in the relationships between science and society.

\section{Open Educational resources}

As Beutner found in 2020 OER - open educational resources are directly connected to MOOCs, elearning and this means also that they are important for aspects of MoRRI (Monitoring the Evolution and Benefits of Responsible Research and Innovation) and the provision of knowledge within the knowledge base for SwafS.

Open educational resources (OER) are useful for teaching, learning, assessment and research purposes. Usually, OER are freely accessible. They are openly licensed texts, media or digital educational assets. Interest in open educational resources has been increasing both internationally and in the European educational landscape for several years. However, the different diverse interests have been changing during the years. In this way, drivers of an ideological, political and economic nature staying equally strong. In contrary, the focus on learning and teaching implementation for the purpose of designing learning and teaching environments are largely ignored.

As early as 2012, the first UNESCO World Congress on Open Educational Resources with over 400 participants was held in Paris, at which the "2012 Paris OER 
Declaration" was adopted. The declaration called on UNESCO member states to promote the creation and use of OER. At the second World Conference on OER, the definition retained its existence and was not changed due to its still existing acceptance:

"OER are teaching, learning and research materials in any medium-digital or otherwisethat reside in the public domain or have been released under an open license that permits no-cost access, use, adaptation and redistribution by others with no or limited restrictions. Open licensing is built within the framework of intellectual property rights as defined by relevant international conventions to respect the authorship of work." (UNESCO 2017)

The resources usually appear under a public licence like the creative commons licences or GNU General Public license.

Typically the discussions about OER are concerning the aspects: (a) create, (b) share and (c) use (see Mc Greal 2013).

The creation processes and standards for the creation are crucial to make sure that many people are informed how to deal with OER and to make sure that they possess the needed knowledge to design OER and so to increase the number of OER available. Sharing OER is often addressed by databases, where the OER are provided to teachers and learners. But, sharing is more than storing, sharing is also finding and creating the awareness that also own materials could be provided as OER. Using OER is very common for teachers, trainers and scientists who are looking for materials and resources available and who can then use them in their own contexts. This is often accompanied by aspects of adjustments, modifications and reuse (see Mc Greal 2013).

A core issue which is not tackled so often is the quality of the created OER and the ways to ensure high quality when there is no payment for the creators and no monitoring body that provides peer review to assure the high quality of the OER. It is important that OER do not lead to wrong knowledge, a lower level of knowledge, or even use tools that radicalise. Within the German project Mapping OER (cf. http://mapping-oer.de) a team of experts stated that Quality Assurance procedures based on criteria catalogues or test procedures are considered to be useful. Beutner ran a project on the design of quality criteria for OER called EUStORE (see Beutner / Schneider 2015, see Beutner Schneider 2016 and Beutner 2016). Within this approach the OER are rated by experts on an online platform using the categories:

- Rights and duties

- Technical Support

- Aims and focus of the OER

- Organisational Information

- Materials 
- Usability

- Content

- Media

- $\quad$ Target Groups

- Sustainability and Sponsoring

- Community (Beutner 2015)

Such OER and quality criteria have to be enhanced in the future to be used within the knowledge base of SwafS. High quality and free public access are important aspects to make the transfer of knowledge between the helixes and especially between science and the public much easier and more effective.

\section{Methodology}

This project delivers on the objectives because it enhances access to the open access Bottom up SwafS knowledge base and provides social actors with the skills for participation with and co-creation of the Bottom up SwafS knowledge base. This is achieved through the methodology using the tool kit, MOOC and systematic training to use the Bottom up SwafS knowledge base mapped to MoRRi. Progress is measured against the scaleable incremental ABCDE rubric (Diagram 1) using Assessment for Personal and Social Learning (Diagram 2) to Empower Young Societal Innovators for Equity and Renewal mapped to the MoRRi and the Sustainable Development Goals. Each of the 12 workshops of the Open Educational Resource Massive Online Open Access Course (MOOC) maps to each of the 12 chapters of the Handbook that accompanies the EYSIER Charter Mark MOOC and Toolkit; Taysum, A. (2019) Education Policy as a Road Map for Achieving the Sustainable Development Goals. Scarborough: Emerald:

Chapter 1 Sustainable Development Goal 4 Quality Education, Inclusion and the Philosophies of Trust

Chapter 2 The Policy Context: Challenging the Crisis of Contemporary Culture and Popularism with ABCDE to Achieve SDG 423

Chapter 3 Assessment for Personal and Social Learning: A Deweyan Perspective for Education and Inclusion

Chapter 4 Creating Democratic Identities for a Social Contract

Chapter 5 Replacing the Hierarchical Master in a Social Contract with Autonomous Citizens Actively Participating within the Force of the Common Whole

Chapter 6 Educational Leaders Using ABCDE to Explore Human Behaviours in Social Contracts in Relation to Embedded and 


\section{Disembedded Economies}

Chapter 7 Groundwork Case Study of Universities' Building Capacity for Education, Inclusion and Philosophies of Trust through Doctoral Study: The Literature and Methodologies

Chapter 8 Case Studies of Higher Education Building Capacity for Education, Inclusion, Identity and Philosophies of Trust through the Doctorate: The Findings

Chapter 9 A Masters 'Level 7 EQF' Training Course to Deliver ABCDE through APSL to EYSIER

Chapter 10 Step-by-Step Application of a Blueprint for Character Development for Evolution (ABCDE) and a Framework for Assessment for Learning and Progress towards Sustainable Development Goals

Chapter 11 To Rationalise a Priori or Not to Rationalise a Priori: Is That an Empirical Question?

Chapter 12 Conclusions to Education Policy as a Road Map for Achieving the Sustainable Development Goals

The target audience for engaging with the EYSIER Charter Mark MOOC and toolkit to achieve an EYSIER Charter Mark Award at Gold, Silver, or Bronze level, are leaders of organisations of the quadruple helix who work with organisational structures to train staff to meet the EYSIER Charter Mark Award criteria using open access participatory data bases with clear peer review guidelines. Each kind of organisation from the quadruple helix identifies the professional challenge they want to ask questions about from their strategic plan (Beutner, 2020, Taysum, 2019). Each organisation within the subgroups of the quadruple helix, has connections to University Faculties that are professional and/or disciplinary. These connections aim to focus on optimising the delivery of organisations' strategic plans efficiently and effectively by accessing and mobilising innovative knowledge created in the University as a hub of knowledge generation for and with society. Thus the MOOC delivers on the objectives of this project as a hybrid of University knowledge xMOOCs and the creation of new knowledge with cMOOCs that build good bridges between the University and the subgroups of the quadruple helix. The thinking tools, MOOC and handbook successfully propel and amplify the impact and reach of innovative knowledge within University faculties and shared in the quadruple helix through new partnerships created by the MOOCs networks to optimise delivery of states' strategic plans, and the participatory candidates/organisation of the MOOC. The University assures the safeguarding of an ethical social contract with and for society by mainstreaming Science With and For Society that is subject to ethical approval processes and practices within all regulatory Ethical Review Boards which helps focus on exploring the Prime Principles (Kant, 1785) of any theories of change that emerge from applying 
ABCDE with APSL to EYSIER (Taysum, 2019). Therefore this project seeks to mobilise the SwafS within Universities, between Universities and between Universities and the subgroups of the quadruple helix in new partnerships. These new partnerships that are kind to people and planet focus on engendering peace and prosperity by meeting the ET2020 four strategic objectives: Making lifelong learning and mobility a reality; Improving the quality and efficiency of education and training;; Promoting equity, social cohesion and active citizenship; Enhancing creativity and innovation, including entrepreneurship, at all levels of education and training. Achieving these map to working towards, and meeting the targets of the 17 Sustainable Development Goals Targets (United Nations, 2016) using MoRRi.

First leaders across all sectors of the quadruple helix will be trained by the consortium including award winners from Science and Business. The training operationalised through the proposal's methodology empowers leaders to build open access bottom up SwafS knowledge bases with the leadership and management teams, their middle management and their staff. The teams engagement with the data to monitor and evaluate progress against the strategic plan are mobilised by the consortium's platform using technologies that cross geographical, intellectual, cultural and economic boundaries. Groundwork case studies to emerge from successful submissions of a Bronze, Silver or Gold EYSIER Charter Mark Award will demonstrate alignment between commercial/learning goals and Sustainable Development Goals. These are then published in the EYSIER Character Mark Award repository of Groundwork Case studies and Moral Principles Open Access Data Base. Those wishing to, may submit their Groundwork case studies for consideration for publication in the Open Access International Peer Reviewed Journal of Groundwork Case studies and Moral Principles (GCMP) to optimise impact and reach of the interactions with the bottom up SwafS knowledge base.

All successful ground work case studies map to the MoRRi and empower Small and Medium enterprises and public service professions to engage with large benchmarking data sets such as the SDGs data sets repository for delivering the 17 SDGs targets aligned to the commercial/learning and teaching/main strategic goals of the organisation.

The methodology includes participants' engagement with the synthesis of implicit knowledge with explicit knowledge, personal knowledge with social knowledge and traditional knowledge with innovative knowledge, new technologies and/or knowledge from previously marginalised groups (see 8 lines of action) and faith and reason (Pring, 2020).

The EYSIER Charter Mark Award (see alisontaysum.com and Taysum's EYSIER MOOC and Charter app on Itunes and GooglePlay) focuses on optimising young people developing the competences of ABCDE using APSL to progress through the incremental $\mathrm{ABCDE}$ framework. Citizens develop philosophies, psychologies and 
ethics of trust to be able trust themselves and others and discern good from bad at all levels of interaction of the SwafS knowledge base personally and socially.

\section{Strategy}

The life of the project is 3 years and self sustaining thereafter;

Year 1 Each Consortium trains the leaders of organisations from the quadruple helix to meet the SwafS 31 objectives and outcomes, and to certify them as Associates to deliver SwafS 31 objectives. This is measured with a basket of indicators verified with 10 successful EYSIER Charter Mark Awards at Bronze, Silver or Gold per consortium member.

Year 2 Each Consortium trains and supports the successful EYSIER Charter Mark Award winners who successfully submit applications that meet threshold levels to train their first 10 leaders of organisations from the quadruple helix to meet the SwafS 31 objectives and outcomes, and to certify them as Associates to deliver SwafS 31 objectives. This is measured with a basket of indicators verified with 100 successful EYSIER Charter Mark Awards at Bronze, Silver or Gold per consortium member.

Year 3 Each Consortium trains and supports the successful EYSIER Charter Mark Award winners who successfully submit applications that meet threshold levels to be accepted to train* to be certified and mentored to train their first 10 leaders of organisations from the quadruple helix to meet the SwafS 31 objectives and outcomes, and to certify them as Associates to deliver SwafS 31 objectives. This is measured with a basket of indicators verified with 100 successful EYSIER Charter Mark Awards at Bronze, Silver or Gold per consortium member. The income generation makes the project financially self-sustaining with opportunities to offer a percentage of the surpluses as bursaries to organisations in nation states that are not cash rich to support their participation with the EYSIER Charter Mark Award.

\section{Impact}

Interactions with the SwafS knowledge bases empowers citizens to have a calm confidence that the pen is mightier than the sword. This is important for building psychologies, philosophies and ethics of trust that empower citizens to become selfregulating. The methods in this proposal using ABCDE with APSL train OA SwafS knowledge consumers how to command scientific argumentation as a tool in negotiation. Interactions with SwafS knowledge bases engenders faith in scientific principles of searching for truth, being inclusive, being critical and committed to generating new knowledge. These principles underpin mitigation processes where citizens as trained consumers of SwafS knowledge have a scientific disposition and belief their voices will be heard and respected when their beliefs and principles do no harm to the self or the other. This is part of the social contract in E of ABCDE when citizens mobilise their knowledge as consumers of scientific research to do their duty and take responsibility for their intentions and acts. This is summarised in Table 1 
ABCDE Incremental Framework with 'Impact of Progress' and 'Measure of Impact of Progress' mapped to Competences of European Qualifications Framework (European Commission, 2020)

\section{Table 1 ABCDE Incremental Framework with 'Impact of Progress' and 'Measure of Impact of Progress' mapped to Competences of European Qualifications Framework (European Commission, 2020)}

\begin{tabular}{|c|c|c|c|}
\hline Action & Impact of Progress & Measure of Impact of Progress & $\begin{array}{l}\text { Competency } \\
\text { European } \\
\text { Qualifications } \\
\text { Framework } \\
\text { (EQF) }\end{array}$ \\
\hline $\begin{array}{l}\text { Stage A } \\
\text { Community } \\
\text { members start } \\
\text { to develop their } \\
\text { sense making } \\
\text { from } \\
\text { observations to } \\
\text { their beliefs by } \\
\text { asking } \\
\text { questions }\end{array}$ & $\begin{array}{l}\text { Communities will be able to } \\
\text { define problems with clarity and } \\
\text { ask good questions. This } \\
\text { change is a first step to } \\
\text { recognising fake news, and } \\
\text { trustworthy news Mapped to the } \\
\text { EYSIER Charter Mark Award to } \\
\text { validate successful delivery of } \\
\text { the objectives of this SwafS } 31 \\
\text { proposal. }\end{array}$ & $\begin{array}{l}\text { Communities demonstrate nuanced } \\
\text { robust and discerning ability to } \\
\text { identify a professional challenge, } \\
\text { and the constructs within it, develop } \\
\text { objectives to deliver new solutions to } \\
\text { old problems and develop sharply } \\
\text { focused research questions that } \\
\text { address the objectives and the } \\
\text { professional challenge, such that the } \\
\text { questions contain half the answer. }\end{array}$ & $\begin{array}{l}\text { Level } 1 \text { of the } \\
\text { EQF } \\
\text { Competences } \\
\text { 'Basic skills } \\
\text { required to } \\
\text { carry out } \\
\text { simple tasks }\end{array}$ \\
\hline $\begin{array}{l}\text { Stage B } \\
\text { Competency to } \\
\text { interrogate the } \\
\text { best that has } \\
\text { been thought } \\
\text { and said about } \\
\text { the constructs } \\
\text { of the } \\
\text { questions. }\end{array}$ & $\begin{array}{l}\text { Communities will be able to } \\
\text { engage with knowledge bases } \\
\text { that allow the synthsis between } \\
\text { personal implicit knowledge and } \\
\text { external scientific knowledge } \\
\text { using Assessment for Personal } \\
\text { and Social Learning (APSL). By } \\
\text { using APSL at Stage B citizens } \\
\text { have a toolkit to engage with } \\
\text { Science with and for Society in } \\
\text { new partnerships between } \\
\text { science and society by i) } \\
\text { examining the constructs in the } \\
\text { questions that map back to their } \\
\text { objectives and particular } \\
\text { challenge/problem, ii) identifying } \\
\text { where the gaps in their } \\
\text { knowledge are, ill) recognising } \\
\text { different kinds of knowledge } \\
\text { such as logical, empirical and/or } \\
\text { ethical that they need to fill their } \\
\text { gap in their knowledge and iv) to } \\
\text { reflect on why these gaps exist }\end{array}$ & $\begin{array}{l}\text { Communities demonstrate nuanced } \\
\text { robust and discerning constructive } \\
\text { critique of different world views in } \\
\text { the bottom up SwafS knowledge } \\
\text { base verified by successful } \\
\text { submission of a grounded case } \\
\text { study mapped to the incremental } \\
\text { ABCDE with APSL and MoRRi that } \\
\text { achieves an EYSIER Charter Mark } \\
\text { Award. }\end{array}$ & $\begin{array}{l}\text { Level } 2 \text { of the } \\
\text { EQF } \\
\text { Competences } \\
\text { 'Basic } \\
\text { cognitive and } \\
\text { practical skills } \\
\text { required to } \\
\text { use relevant } \\
\text { information in } \\
\text { order to carry } \\
\text { out tasks and } \\
\text { to solve } \\
\text { routine } \\
\text { problems } \\
\text { using simple } \\
\text { rules and } \\
\text { tools' }\end{array}$ \\
\hline
\end{tabular}




\begin{tabular}{|c|c|c|c|}
\hline & $\begin{array}{l}\text { in relation to their access to the } \\
\text { knowledge bases, }\end{array}$ & & \\
\hline $\begin{array}{l}\text { Stage C } \\
\text { Competency to } \\
\text { design and } \\
\text { implement } \\
\text { methods that } \\
\text { are robust with } \\
\text { high quality } \\
\text { dimensions } \\
\text { that yield } \\
\text { baseline data } \\
\text { and impact } \\
\text { data }\end{array}$ & $\begin{array}{l}\text { Communities will know how to } \\
\text { collect data and mobilise it to co- } \\
\text { create evidence informed, } \\
\text { logical and ethical impact } \\
\text { strategies that are culturally } \\
\text { relevant to their educational } \\
\text { organisation. } \\
\text { Communities build } \\
\text { interdependent and } \\
\text { interconnected indusionary } \\
\text { partnerships and communities of } \\
\text { practice for the cultivation of } \\
\text { impact strategies in their bottom } \\
\text { up interactions with the SwafS } \\
\text { knowledge base. This develops } \\
\text { cultural alignment for equity } \\
\text { which correlates with developing } \\
\text { psychologies, philosophies and } \\
\text { ethics of trust. } \\
\text { Mapped to EYSIER Charter } \\
\text { Mark Award basket of indicators } \\
\text { at Bronze, Silver or Gold (MoRRi } \\
\text { and SDG KPIs). }\end{array}$ & $\begin{array}{l}\text { Communities demonstrate nuanced } \\
\text { robust and discerning constructive } \\
\text { critique of different world views in } \\
\text { each of the partner institutions } \\
\text { verified by tolerance for others } \\
\text { supported by the HEls delivered } \\
\text { through the work packages. }\end{array}$ & $\begin{array}{l}\text { Level } 3 \text { of the } \\
\text { EQF } \\
\text { Competences } \\
\text { 'A range of } \\
\text { cognitive and } \\
\text { practical skills } \\
\text { required to } \\
\text { accomplish } \\
\text { tasks and } \\
\text { solve } \\
\text { problems by } \\
\text { selecting and } \\
\text { applying basic } \\
\text { methods, } \\
\text { tools, } \\
\text { materials and } \\
\text { information'. }\end{array}$ \\
\hline
\end{tabular}




\begin{tabular}{|c|c|c|c|}
\hline $\begin{array}{l}\text { Stage D } \\
\text { Competency to } \\
\text { develop } \\
\text { hypotheses } \\
\text { from data that } \\
\text { can be tested } \\
\text { for proof of } \\
\text { concept }\end{array}$ & $\begin{array}{l}\text { Hypotheses are verified by } \\
\text { indicators of progress with } \\
\text { targets for an evolving post- } \\
\text { racial community and evolving } \\
\text { gender relationships that the } \\
\text { community members set for } \\
\text { themselves and regulate. } \\
\text { Their communities are } \\
\text { characterised by tolerance and } \\
\text { understanding for those of } \\
\text { different faiths and none, race, } \\
\text { ethnicity, and citizenship status } \\
\text { including refugees. Mapped to } \\
\text { EYSIER Charter Mark Award } \\
\text { basket of indicators at Bronze, } \\
\text { Silver or Gold (MoRRi and SDG } \\
\text { KPIs). }\end{array}$ & $\begin{array}{l}\text { Communities will have } \\
\text { benchmarked clear and transparent } \\
\text { ways to resolve conflict in a } \\
\text { supportive climate that does not } \\
\text { disempower community members } \\
\text { to make them fearful and more } \\
\text { compliant with confusing systems. } \\
\text { Any unresolved conflict Is reported } \\
\text { to the Senior Leader of the } \\
\text { Education Governance System who } \\
\text { investigates and reports to the } \\
\text { Governing Body and Parents' } \\
\text { Teachers' Association who } \\
\text { escalates to authorities if the } \\
\text { conflict is not resolved. }\end{array}$ & $\begin{array}{l}\text { evel } 4 \text { of the } \\
\text { EQF } \\
\text { Competences } \\
\text { 'A range of } \\
\text { cognitive and } \\
\text { practical skills } \\
\text { required to } \\
\text { generate } \\
\text { solutionsto } \\
\text { specific } \\
\text { problems in a } \\
\text { field of work or } \\
\text { study'. }\end{array}$ \\
\hline $\begin{array}{l}\text { Stage E } \\
\text { Competency to } \\
\text { extrapolate } \\
\text { prime } \\
\text { principles from } \\
\text { hypotheses } \\
\text { with proof } \\
\quad \text { of } \\
\text { concept, from } \\
\text { this point they } \\
\text { can develop } \\
\text { the } \\
\text { competency to } \\
\text { apply ABCDE } \\
\text { in the } \\
\text { Quadruple } \\
\text { Helix to } \\
\text { achieve } \\
\text { ET2020 four } \\
\text { Strategic } \\
\text { objectives and } \\
\text { SDG } 4.7 \text { which } \\
\text { Empowers } \\
\text { Young Societal } \\
\text { Innovators for } \\
\text { Equity and } \\
\text { Renewal } \\
\text { (EYSIER) to } \\
\text { achieve all } \\
\text { SDGs and } \\
\text { build }\end{array}$ & $\begin{array}{l}\text { The multiplier effect will be } \\
\text { made possible by disseminating } \\
\text { the results with policy makers, } \\
\text { the Ministry of Education who } \\
\text { will be attracted to mainstream } \\
\text { the objectives, methodologies, } \\
\text { results based on the evaluation } \\
\text { through measures of indicators } \\
\text { of progress and impact } \\
\text { validated by the EYSIER } \\
\text { Charter Mark Awards achieved. } \\
\text { The capacity will also be built by } \\
\text { an ambitious } \\
\quad \text { dissemination } \\
\text { programme that will include } \\
\text { social media with a reach in } \\
\text { excess of } 500,000, \text { conferences } \\
\text { electronic part of the civic } \\
\text { society of the quadruple helix. } \\
\text { Reach, and impact on } \\
\text { interactions with bottom up OA } \\
\text { SwafS knowledge base. } \\
\text { Building effective co-operation } \\
\text { between science and society by } \\
\text { training leaders of the four } \\
\text { spheres of the quadruple helix } \\
\text { to use a toolkit mapped to the } \\
\text { MoRRi that optimises delivery of } \\
\text { their organisation's strategic } \\
\text { plan through interactions with } \\
\text { open access Bottom up SwafS }\end{array}$ & $\begin{array}{l}\text { Policy makers mainstream ABCDE. } \\
\text { The evaluation is benchmarked to a } \\
\text { basket of indicators in the EYSIER } \\
\text { Charter Mark rubric mapped to the } \\
\text { incremental ABCDE with APSL and } \\
\text { MoRRi to foster the recruitment of } \\
\text { new talent for science using this } \\
\text { proposal's methodology that } \\
\text { delivers interactions with a bottom } \\
\text { up SwafS knowledge base that } \\
\text { build scientific groups for all in } \\
\text { STEM, the Social Sciences and } \\
\text { Arts and Humanities. } \\
\text { As consumers of bottom up OA } \\
\text { SwafS knowledge bases the } \\
\text { methods will pair scientific } \\
\text { excellence with social awareness } \\
\text { and responsibility raising } \\
\text { awareness of what to do to interact } \\
\text { with the } 8 \text { lines of action, how to do } \\
\text { this using the methodology of this } \\
\text { RiA and why these intentions and } \\
\text { acts are of personal and social } \\
\text { benefit to amplify the main SwafS' } \\
\text { objectives. This particularly focuses } \\
\text { on developing calm climates that } \\
\text { empower marginalised groups with } \\
\text { scientific knowledge and } \\
\text { dispositions for scientific } \\
\text { deliberation to navigate turbulence }\end{array}$ & $\begin{array}{l}\text { Level } 5 \text { of the } \\
\text { EQF } \\
\text { Competences } \\
\text { 'A } \\
\text { comprehensive } \\
\text { range of } \\
\text { cognitive and } \\
\text { practical skills } \\
\text { required to } \\
\text { develop } \\
\text { creative } \\
\text { solutions to } \\
\text { abstract } \\
\text { problems'. }\end{array}$ \\
\hline
\end{tabular}




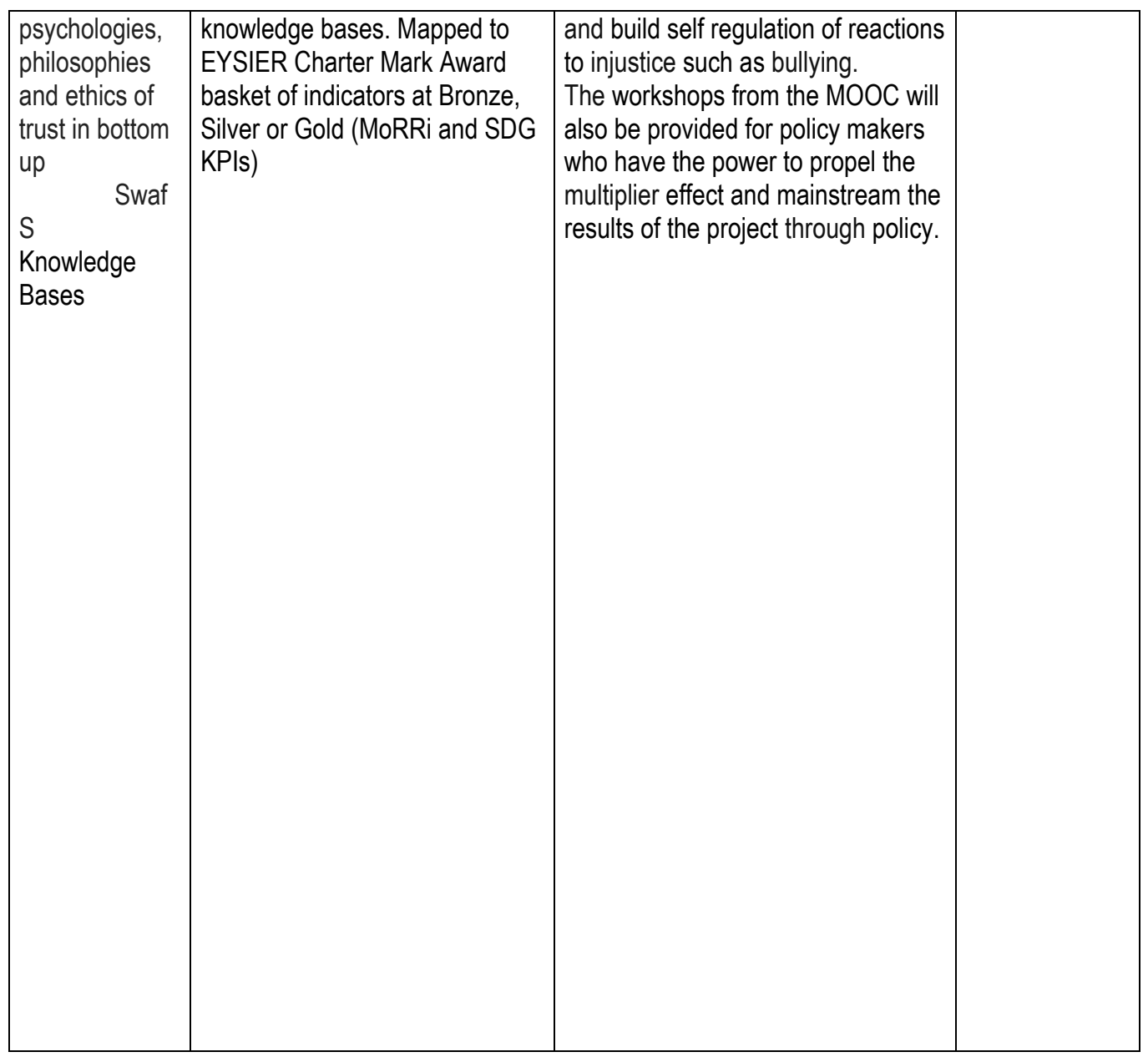




\begin{tabular}{|c|c|c|c|}
\hline \begin{tabular}{l} 
F. \\
Competency \\
to apply \\
ABODE in \\
\multicolumn{1}{c}{ the } \\
Quadruple \\
Helix to \\
achieve \\
ET2020 four \\
Strategic \\
objectives and \\
SDG 4.7 \\
which \\
Empowers \\
Young \\
Societal \\
Innovators for \\
Equity and \\
Renewal \\
(EYSIER) to \\
achieve all \\
SDGs.
\end{tabular} & $\begin{array}{l}\text { Ability to Provide ABODE with } \\
\text { APSL to EYSIER with } \\
\text { successful cohorts meeting } \\
\text { ABODE with APSL Impact of } \\
\text { Progress, KPIs, and } \\
\text { successfully gaining EYSIER } \\
\text { Charter Mark Award }\end{array}$ & $\begin{array}{l}\text { Ability to evaluate the evaluation tool } \\
\text { ABCDE with APSL to EYSIER }\end{array}$ & $\begin{array}{l}\text { Level } 6 \text { of the } \\
\text { EQF } \\
\text { Competences } \\
\text { 'Advanced } \\
\text { skills, } \\
\text { demonstrating } \\
\text { mastery and } \\
\text { innovation, } \\
\text { required to } \\
\text { solve complex } \\
\text { and } \\
\text { unpredictable } \\
\text { problems in a } \\
\text { specialised } \\
\text { field of work or } \\
\text { study'. }\end{array}$ \\
\hline $\begin{array}{l}\text { G. } \\
\text { Competency } \\
\text { to train } \\
\text { teachers and } \\
\text { teacher } \\
\text { leaders to } \\
\text { implement } \\
\text { ABODE and } \\
\text { develop } \\
\text { leadership to } \\
\text { build capacity } \\
\text { with policy } \\
\text { makers in the } \\
\text { quadruple } \\
\text { helix to } \\
\text { mainstream } \\
\text { ABODE with } \\
\text { APSL to } \\
\text { EYSIER }\end{array}$ & $\begin{array}{l}\text { Ability to train providers of } \\
\text { ABCDE with APSL to EYSIER } \\
\text { with successful cohorts } \\
\text { meeting ABCDE with APSL } \\
\text { Impact of Progress, KPIs, and } \\
\text { successfully gaining EYSIER } \\
\text { Charter Mark Award }\end{array}$ & $\begin{array}{l}\text { Ability to train evaluators of the } \\
\text { evaluation tool ABCDE with APSL to } \\
\text { EYSIER }\end{array}$ & $\begin{array}{l}\text { Level } 7 \text { of the } \\
\text { EQF } \\
\text { Competences } \\
\text { 'Specialised } \\
\text { problemsolving } \\
\text { skills required } \\
\text { in research } \\
\text { and/or } \\
\text { innovation in } \\
\text { order to } \\
\text { develop new } \\
\text { knowledge and } \\
\text { procedures } \\
\text { and to } \\
\text { integrate } \\
\text { knowledge } \\
\text { from different } \\
\text { fields. }\end{array}$ \\
\hline
\end{tabular}




\begin{tabular}{|c|c|c|c|}
\hline $\begin{array}{l}\text { H. Competency } \\
\text { to teach the } \\
\text { leaders to } \\
\text { implement } \\
\text { ABCDE with } \\
\text { APSL to } \\
\text { EYSIER }\end{array}$ & $\begin{array}{l}\text { Ability to safeguard the } \\
\text { empirical, logical, moral and } \\
\text { ethical purpose of implementing } \\
\text { ABCDE with APSL to EYSIER }\end{array}$ & $\begin{array}{l}\text { Ability to safeguard the continuous } \\
\text { evaluation of the evaluation tool } \\
\text { ABCDE with APSL to EYSIER, } \\
\text { particularly at the interface where } \\
\text { traditional knowledge meets new } \\
\text { technologies that reveal new } \\
\text { professional challenges that can } \\
\text { propel or otherwise, human } \\
\text { evolution in meeting the targets of } \\
\text { the SDGs. }\end{array}$ & $\begin{array}{l}\text { Level } 8 \text { of the } \\
\text { EQF } \\
\text { Competences } \\
\text { 'The most } \\
\text { advanced and } \\
\text { specialised } \\
\text { skills and } \\
\text { techniques, } \\
\text { including } \\
\text { synthesis and } \\
\text { evaluation, } \\
\text { required to } \\
\text { solve critical } \\
\text { problems } \\
\text { research in } \\
\text { and/or } \\
\text { innovation and } \\
\text { to extend and } \\
\text { redefine } \\
\text { existing } \\
\text { knowledge or } \\
\text { professional } \\
\text { practice'. }\end{array}$ \\
\hline
\end{tabular}

The proposal focuses on evolving gender relationships as core to building equity and trust in bottom up OA SwafS knowledge base with the school as a hub and the Consortium's HEIs as a broker of the bottom up OA SwafS knowledge bases across faculties and the quadruple helix.

Community members will mobilise their knowledge skills and experience gained from the project to plan and implement full participation in the bottom up OA SwafS knowledge base to mainstream wider knowledge in the wider societal across the quadruple helix.

Community members can gain the thinking tools to make good decisions about the quality dimensions of the research they consume. They can readily transfer these skills to hold states people accountable for building infrastructure and effective cooperation between science and society that fosters the recruitment of new talent for science that pairs scientific excellence with social awareness and responsibility.

The ambition is to build effective co-operation between science and society by training leaders of the four spheres of the quadruple helix to use a toolkit mapped to the MoRRi that optimises delivery of their organisation's strategic plan through interactions with open access Bottom up SwafS knowledge bases. 
Further, to foster the recruitment of new talent for science using a toolkit that delivers interactions with a bottom up SwafS knowledge base that builds scientific groups for all in STEM, the Social Sciences and Arts and Humanities.

Finally to pair scientific excellence with social awareness and responsibility raising awareness of what to do to interact with the 8 lines of action, how to do this using the methodology of this RiA and why these intentions and acts are of personal and social benefit and amplify the main SwafS' objectives.

An initial pilot of this study is reported in the Italian Journal of Sociology of Education (Taysum et al, 2020) and in the International Journal of Leadership in Education. For example Arar and Taysum (2020) found that a distinctive mark of distributed leadership using whole school inquiry led inter-cultural change. The change facilitated knowledge exchange, mobilisation, and dissemination activities that Empowered staff and young people to become Societal Innovators for Equity and Renewal which improved student outcomes between - 17\% and $27 \%$ The research reveals that distributed leadership, sharing aims, themes and methods through whole school inquiry developed new inter-cultural understandings. It built respect, trust, and local research priorities and practices in communities of diverse race, ethnicity, culture, and religions, for both citizens and refugees. Members of diverse communities were able to hold each other to account, and became more autonomous in their plans for the future in coping with gaps in status in both studied contexts.

\section{Conclusions}

This paper presents a boundary crossing pilot study that addresses the professional challenge that civic society has a deep mistrust of scientific evidence, experts, and psychologies, philosophies and ethics of trust. At the same time, in the recovery from Covid 19 disruption, it is scientific data and its means of production, exchange, transmission and feedback from diverse contexts that will optimise a successful recovery. A successful recovery aligns commercial, cultural, political and sustainable goals in diverse contexts that respects diverse ways of knowing and being in a new social contract. The paper addresses the professional challenge with Empowering Young Societal Innovators for Equity and Renewal Charter Mark from Education Policy as A Road Map to Achieving the Sustainable Development Goals (Taysum, 2019) with Beutner (2020) use of MOOCs for leaders to deliver their organisation's strategic plan. Citizens from the quadruple helix; Universities, Industry, Governance Systems and Citizens and Social Media achieve this by meeting the Intended Learning Outcomes of curriculums in examinations that map to competences in the labour market. The competences provide ways of thinking and doing for problem solving, in a recovery context, that meet Organisation's Strategic Objectives. Meeting the competences from the European Qualifications Framework are mapped to A Blueprint for Character Development for Evolution (ABCDE) using Assessment for Personal and Social Learning (APSL) and MoRRi demonstrates that they can: 
explicitly participate with intention and acts in an ethical social contract between citizens, the economy, the government and independent legislator drawing on Bottom up SwafS knowledge bases;

explicitly articulate how and in what ways participation with a social contract engenders inclusionary regimes of social justice and the precautionary principle for all;

build effective co-operation between science and society with leaders of the four spheres of the quadruple helix;

interact with open access Bottom up SwafS knowledge bases that foster recruitment of new talent for scientific careers in STEM, the Social Sciences and Arts and Humanities by pairing scientific excellence with social awareness, responsibility and eliminating intersectionalities of discrimination (gender, race, protected characteristics of Equality Act of 2010).

Our consortium's support of organisations preparing their EYSIER Charter Mark Award will engender research excellence using the EYSIER Charter Mark Toolkit and MOOC. Gaps in relation to people's needs and concerns are revealed in Stage A of ABCDE Level 1 Competence of the European Qualifications Framework (EQF) to ask good questions is developed. At Stage B of ABCDE Level 2 Competence of the EQF to access the Open Access bottom up SwafS knowledge base to engage and participate with the best that has been thought and said from the SwafS knowledge bases is developed. They will use the Open Access bottom up SwafS knowledge bases to synthesise their implicit personal knowledge and beliefs with explicit social knowledge. This can be done at Macro level (international level) for example Governance Systems, the SDGs databases, large international organisations, The Meso level at national level for example national governance systems, and micro level for example at regional levels and Small and Medium Enterprises. At stage $C$ of ABCDE, Level 3 Competence of the EQF to create and implement robust and quality methodologies to assure the quality dimensions of the research to collect and analyse trustworthy and valid data is developed. At Stage D of ABCDE, Level 4 Competence of the EQF they will present evidence informed, logic and ethical theories of change that align commercial interests with humanitarian evolutionary interests and sustainable development interests and test hypotheses for proof of concept. At Stage E of ABCDE Level 5 Competence of the EQF they will be able to discern good from bad and identify prime moral principles. At this stage the implications of deep changes in science and innovation will be bridged to optimise impact in the quadruple helix through interactions with society, the economy for commercial, evolutionary and sustainable benefit. For example the transition to open science and open innovation are revealed. Stage F, Level 6 Competence of the EQF demonstrates Mastery in the successful implementation of ABCDE in the social helix. Stage $G$ is a Level 7 Competence of the EQF demonstrating specialisation and Stage $\mathrm{H}$ is a Level 8 Competence of the EQF demonstrating expert, trainer of leaders and gate-keeper of the field. 
All resultant changes in the relationships between science and society can be Assessed for Personal and Social Learning and the movement of knowledge up and down the communication lines mapped to ABCDE, MoRRi and the International, and National targets of the Sustainable Development Goals that realistically align commercial, cultural, and political goals of diverse organisations in an inclusionary, just, prudent yet risk taking quadruple helix that respects diverse cultural heritages and all faiths and none. These meet organisations' strategies and mission statements that socialise risks, investment and rewards in the quadruple helix logically, ethically and using the bottom up OA SwafS evidence base demonstrating social benefit.

$\mathrm{ABCDE}$ is an incremental rubric that organisation members, including students, can map their developing personal and social narrative capital against in their transition from immature to mature self-governing autonomous citizens in becoming and is therefore of personal benefit. Thus, at $\mathrm{E}$ of $\mathrm{ABCDE}$, citizens can explicitly understand their duties and rights that do no harm to the self or other, in a new social contract they could have written themselves. This agrees with Kant (1785) who identifies this is a/the prime moral principle and optimises alignment of commercial interests, humanitarian evolutionary interests, inclusionary interests, and interests of social justice, prudence and risk taking in the amplification of ethical entrepreneurial economies with and for all the people.

Credits: Hauwa Imam, University of Abuja, Nigeria - Ueda Midori, NIER, Japan Daniela Canfarotta, Universita di Palermo e di Burgos, Italy - Raquel Casado-Munoz, University of Burgos, Spain -Mihaela-Viorica $\mathrm{Ru}^{\wedge}$ itoru, University of Helsinki, Finland - Ferit Hysa, University of Elbasan Aleksander Xhuvani - Raj Pathak, European Learning Network - Aigerim Mynbayeva, Al- Farabi Kazakh National University - Zarina Yelbayeva, Al-Farabi Kazakh National University - Victor Timchenko, Herzen State Pedagogical University of Russia - Sergey Trapitsin, Herzen State Pedagogical University of Russia - Victoria Pogosian, Herzen State Pedagogical University of Russia - Elena Tropinova, Saint Petersburg State University - Abdul Saboor, Agriculture University, Rawalpindi - Paul Newton, University of Saskatchewan, Canada - Sam McGuinness, University of Ulster, N. Ireland - Khalid Arar, Texas State University, US - Freddy James, The University of the West Indies, Trinidad

\section{References}

[1] Ball, S. (2006) Education Policy and Social Class. London: Routledge Taylor and Francis Group.

[2] Beutner, M. / Schneider, J. N. (2015): Open Educational Resources in der aktuellen Bildungslandschaft: Motivation zur Teilung und Nutzung. In: Kolner Zeitschrift fur Wirtschaft und Padagogik. 30 Jg., Heft 58, Koln 2015, S. 3-32.

[3] Beutner, M. / Pechuel, R. (2013): Task based authentic Serious Games in 
vocational and further education on basis of the PVEC -Paderborn Vocational Education Concept for elearning: The Copy Job - A Bid Comparison of Suppliers. In: Bastiaens, T. / Marks, G. (Eds.), Proceedings of World Conference on E-Learning in Corporate, Government, Healthcare, and Higher Education 2013 (pp. 931-939). Chesapeake, VA: AACE.

[4] On the internet: http://www.editlib.org/p/114971/. Date: 26.06 .2014

[5] Beutner, M. (2015) The EU-StORe project - Quality criteria for the rating of OER. EU- StORe Conference $2^{\text {nd }}$ of July 2015, Paderborn 2015.

[6] Beutner, M / Schneider, J. (2016) The OER Quality Standards. In: Beutner, M. (Hrsg.): OER - Quality Standards, Implementation, Sharing and Use. Results and Discussions on the basis of the EU-StORe project. Koln 2016, S. 29-41.

[7] Beutner, M. (2016) EU-StORe - European Standards for Open Education and Open Learning Resources. Online-Handbuch fur Trainer und Lehrer. Wie hochqualitative OER nach den EU-StORe Qualitatsstandards fur Open Educational Resources gestaltet werden konnen. Paderborn 2016.

[8] Beutner, M. (2018) Berufsbildungsevaluation. Ein Lehrbuch fur Berufs- und Wirtschaftspadagogen, Studierende des Lehramts an berufsbildenden Schulen sowie Theorie und Praxis. 2. Aufl. Koln 2018.

[9] Beutner, M. (2020) Media in Times of Corona - The Use of MOOCs by Teachers and Trainers. EdMedia2020. Currently in print. Amsterdam 2020. P.1-6.

[10] Beutner, M. / Pechuel, R. (2017): „Micro Units - A New Approach to Making Learning Truly Mobile. In: Proceedings of the SITE Conference 2017. Society for Information Technology \& Teacher Education. SITE 2017 - Austin, TX, United States, March 5-9, 2017, Austin, Texas 2017

[11] Buchmann, D. (2013): Digitales Lernen. MOOCs auf den Punkt gebracht. Digital Kompakt LfM, 7.

[12] Bhaskar, R. (2008) A realist theory of science. London: Verso Books.

[13] Bourdieu, P. (1993) The Field of Cultural Production. London: Polity Press.

[14] Carayannis, E. G. / Campbell, D. F. J. (2011) : Open Innovation Diplomacy and a 21st Century Fractal Research, Education and Innovation (FREIE) Ecosystem: Building on the Quadruple and Quintuple Helix Innovation Concepts and the "Mode 3" Knowledge Production System. J Knowl Econ (2011) 2:327-372.

[15] Dewey, J. (1909). Moral principles in education. New York, NY: The Riverside Press Cambridge.

[16] Fidalgo-Blanco, A., Sein-Echauluc, ML, Garci'a-Penalvo, (2016) From massive access to cooperation: lessons learned and proven results of a hybrid 
xMOOC/cMOOC pedagogical approach to MOOCs International Journal of Educational Technology in Higher Education 13 1, 1-24.

[17] Guba, E. / Lincoln, Y. S. (1989): Fourth generation evaluation. Newbury Park 1989.Horizon (2020) Science with and For Society Call 31 available here;

[18] https://ec.europa.eu/info/funding-

[19] tenders/opportunities/portal/screen/opportunities/topic-details/swafs31-2020 accessed 10th May 2020.

[20] Kant, I. (1785) Groundwork of the metaphysics of morals. London: HarperCollins.

[21] Karall, D. (2015) Massive Open Online Courses (MOOCs) und ihre

[22] Anwendungsmo glichkeiten im Schulunterricht Informatik. (Doctoral dissertation, uniwien) Mapping OER (2016): Mapping OER. http://mappingoer.de accessed 13th May 2020.

[23] Kirkpatrick, D. L. (1959a) Techniques for evaluating training programs. Part 1 - reaction. Journal of American Society for Training and Development, Jg. 13, Heft 11, S. 3-9.

[24] Kirkpatrick, D. L. (1959b) Techniques for evaluating training programs. Part 2 - learning. Journal of American Society for Training and Development, Jg. 13, Heft 12, S. 21-26.

[25] Kirkpatrick, D. L. (1959c) Techniques for evaluating training programs. Part 3 - behavior. Journal of American Society for Training and Development, Jg. 14, Heft 1, S.13-18.

[26] Kirkpatrick, D. L. (1960a) Techniques for evaluating training programs. Part 4 - results. Journal of American Society for Training and Development, Jg. 14, Heft 2, S.28-32.

[27] Kirkpatrick, D. L. (1960b) Techniques for evaluating training programs: Part 4 - results. Journal of American Society for Training \& Development, 13(11). S. 3-9.

[28] Pring, R. (2020) Challenges for Religious Education: Is There a Disconnect Between Faith and Reason? London: Routledge.

[29] McGreal, R. (2013) Creating, Using and Sharing Open Educational Resources. Commonwealth of Learning. Konwledge Series. Vancouver 2013.

[30] Plato (The Dialogues of Plato. An Open Access Resource Available at: https://www.sacred-texts.com/cla/plato/index.htm May 2020.

[31] Scriven, M. (2007) The logic of evaluation. Claremont Graduate University. 03. July 2007. Online: http://homepages.wmich.edu/ mscriven/. accessed $05^{\text {th }}$ 
November 2007.

[32] Stake, R. E. (1975) Programm Evaluation, Particularly Responsive Evaluation Occasional Paper No 5, Kalamazoo, MI: Western Michigan University Evaluation Center.

[33] Taysum, A. and Collins Ayanlaja, C. (2020) Commonalities in schools, education policy, and education systems around the world in neoliberalism; are the kids okay? in Neoliberalism and Education Systems in Conflict: Exploring Challenges Across the Globe. London: Routledge.

[34] Taysum et al's (2020) Empowering Young Societal Innovators for Equity and Renewal Charter Mark available at www.alisontaysum.com

[35] Taysum's (2020) EYSIER MOOC and Charter Mark App Available at:

[36] https://play.google.com/store/apps/details?id=com.alisontaysumapp accessed $10^{\text {th }}$ May 2020.

[37] Taysum's (2020) EYSIER MOOC and Charter Mark App available at: Itunes Store https://apps.apple.com/us/app/taysums-eysier-mooccharter/id1511590843?ls=1 accessed 10th May 2020.

[38] Taysum, A. (2019) Education Policy as a A Roadmap to Achieve the Sustainable Development Goals. Effecting a Paradigm Shift for Peace and Prosperity. Scarborough: Emerald.

[39] Taysum, A. And Arar, K. (2018) Turbulence, Empowerment and Marginalised Groups in International Education Governance Systems. Scarborough Emerald.

[40] https://twitter.com/AlisonTaysum/status/1071297298846674944

[41] Taysum, A. (2017) 'Systems Theory and education: A philosophical enquiry into Education Systems Theory' In P. Higgs, and Y. Waghid (eds) A Reader for Philosophy of Education1, 1. South Africa: Juta.

[42] UNESCO (2017) Second WORLD OERCONGRESS LJUBLJANA OERACTION PLAN 2017. Online:

[43] https://en.unesco.org/sites/default/files/ljubljana_oer_action_plan_2017.p df accessed $13^{\text {th }}$ May 2020. 